\title{
Linkedln CoFounder: Start with a Team, Not an Idea
}

Konstantin Guericke (Linkedln)

\author{
KEYWORDS: Social Media \& Networks, \\ Entrepreneurship, Startups, Team Development, Learn \\ From Leaders.
}

EDITOR'S NOTE: This essay by one of five cofounders of Linkedln, the 500 million-member social network for professionals, is part of our EIX feature entitled "The Entrepreneur Essay." Entrepreneurs who are famous in their own right, or who founded or headed famous companies, will share their wisdom on factors that have been crucial to their success.

Konstantin Guericke headed marketing during Linkedln's genesis in 2002 and its first years, including the critical phase of adding a paid service in 2006 to its free services. In December 2016 Microsoft purchased Linkedln for \$26 billion. Guericke left Linkedln at the end of 2006 to become CEO of Jaxtr, a company that sought to combine social media with mobile phone technology. He also was a partner at Earlybird, a venture capital firm based in his native Germany, and served as a board member for RallyPoint Networks, Inc., a social media site for military ventures.

Today Guericke is an independent director for Doximity, a Linkedln-type network exclusively for physicians. He also serves as a mentor for StartX, a student-led startup accelerator, and mentors students at his alma mater, Stanford University.

Guericke's Linkedln experiences taught him the value of a great startup team. In this essay, he argues that surrounding yourself with great thinkers and honest advisers matters more than the business idea itself.

In 1997 a mutual friend introduced me to Reid Hoffman, my future cofounder at Linkedln. Both Reid and I liked to talk about our business ideas with her, and finally she concluded that we really should be talking to each other. During the early days of our professional friendship, Reid and I had many conversations about the types of businesses that might work. We ultimately agreed on a service that could do for other professionals what our mutual friend had done for us: make productive business relationships possible by introducing people to each other.

The experience taught me that great minds who can work well together matter more than great ideas when you're launching a company. When entrepreneurs surround themselves with smart people - and use them to test, develop and perfect their ideas - the most viable ideas emerge and their company has the greatest chance for success.

Too many new entrepreneurs think it's the other way around. They feel they should rack their brains for a novel idea, then convince others to help them develop it. What they don't realize is that most of their ideas will fail, but the relationships they form and the lessons they learn in the company of great minds will last forever.

That dramatically increases their odds of success over the long term. Whenever you try to do something new, most people by definition will think it's a stupid idea. A far better approach is to find people you'll want to do things with, then pursue some stupid ideas together until you land on one that may not be so stupid after all.

This is the process that made Linkedln's launch successful.

\section{The "Crazy" Ideas That Preceded Linkedln}

Our Linkedln launch team started as a group of people who wanted to work together. But we were not sure on what. Reid, who had worked at PayPal and other ventures, was the CEO. I had designed my own major at Stanford and could have gone in any direction; I picked a marketing role. Our three other cofounders were technology and design experts.

It was unusual to have five co-founders for an organization, and it's not something l'd recommend 
because it can be unwieldy, especially when quick decision-making is required. Most startups do best with two or three co-founders. But in our case it worked.

In our informal talks before Linkedln was a company, Reid and I batted around many crazy business ideas: better phone systems, self-updating address books, online petitions, even a site to memorialize the dead. Ultimately, we agreed on an online network that would do for others what our mutual friend did for us: introduce professionals to one another.

Once we developed the concept for Linkedln, our cofounders' professional relationships helped it reach about 4,500 members within just a few days. We knew a lot of influential people who, because they trusted us, were willing to join this new network and recruit others. These personal relationships made it possible for us to test Linkedln in its earliest stages.

Skepticism was part of our process, and having great thinkers on board guaranteed a healthy dose of it.

I wrote a list of 10 reasons Linkedln would never work. Lists like this are very useful for entrepreneurs. When you get too excited, it helps make sure you don't get carried away. One concern was that professionals would not want to put their professional profiles on the web - at the time, resumes were kept in a briefcase -- or share their valuable Rolodexes, which many of them guarded fiercely.

We also wondered if we could surpass some of the wellfunded business networking sites that were already out there. These doubts, plus the vetting we received from one another, helped us anticipate issues and build something that accomplished what we wanted it to do. And once we surpassed our competitors in membership and had momentum on our side, we refocused our effort on generating revenue.

The result today is a company that has more than 500 million members and brings in more than $\$ 1$ billion a quarter in revenue.

\section{The Key Entrepreneurial Lessons I've Learned at LinkedIn (and Beyond)}

There are four big ones, and many smaller ones:

\section{Start with a team rather than an idea}

When you have nothing, it is almost impossible to convince others to join your crazy mission. It's a Catch 22: people won't join your team if the idea sounds too crazy, and if they do join it might mean your idea is not really crazy enough to make a dent in the universe. But when people come up with a crazy idea together, they have equal stakes in it. When your team works together to choose and nurture an idea, you will stick together through the inevitable dark times. That kind of cohesion and excitement will attract other smart pioneers to your team, even if the outside world hasn't validated your idea yet..

\section{Pick a problem that you'll be glad you tried to solve}

Pick something you are passionate about. Even if you fail, you will be glad you gave it a shot, instead of disappointed in yourself for never having tried to solve it. I saw firsthand how inefficient and frustrating it was to connect with the right people in the business realm. The problem was universal, affecting not only me but also my peers and people in every industry and every country. I thought about how much human potential could be unleashed if we could take this sand out of the gears of the global economic system. I thought about how much better my professional life would be if I could just connect with the right people more easily. My greatest joy is when I hear from people how much time Linkedln saves them and how they feel they could not really imagine doing business without it anymore.

\section{Become highly adept at giving and getting feedback}

Done right, critiquing is a very constructive process. That means being honest without being mean. Reid and I would get together once a week and bounce one or two different ideas off each other. Then we would tear apart each other's ideas, but not in a mean way.

Reid's feedback served as a sharpening stone that challenged my thinking and honed my ideas; my feedback did the same for him. I always knew he was listening to me and he was unfailingly thoughtful, but he was not a cheerleader. He was frank in pointing out the flaws in my ideas and he didn't sugarcoat things. He'd also steer me towards other people whose perspectives would be valuable.

Our own interactions helped refine our vision for Linkedln as a place for fruitful connections and honest exchanges -- a way to use computers and networks to 
help millions of professionals do what Reid and I were doing for each other.

\section{Take on different roles}

Graduates who go to work for big, established companies get exposure to only a tiny sliver of what they'd get in an entrepreneurial venture, where you need to do it all. The first startup I joined right out of college had only 15 people; within six months, I was entrusted with starting its German subsidiary.

Finding the right role in a new company with wide-open frontiers is a trial-and-error process. Because you'll be exposed to a wide range of responsibilities, within a short time you should be able to discern what you like and where you are strongest. And your experiences at one job will help direct your next move.

I left Linkedln for the chance to become a CEO at a firm called Jaxtr, but I quickly found that I missed the Linkedln experience of doing things myself. I was busy overseeing all of Jaxtr but felt it did not play to my strengths. So after I did this for a while, I left to become a venture capitalist -- then realized through that experience that I liked mentoring far more than fundraising and investing. Today some personal experiences are getting me excited about a project in the non-profit realm.

\section{And finally...}

First-time entrepreneurs should embrace the fact that while their chances of failure are high, they won't be happy doing anything else.

When I was nearing graduation and thinking about my own career options, I met some Stanford graduates who had gone into investment banking. They were making lots of money but were very unhappy. I spoke with management consultants who traveled to glamorous places, but they also were very unhappy.

Then I met an entrepreneur whose company had completely cratered, and yet he wanted to do it all over again.

From my own experience as an entrepreneur, I've learned that the people who accompany you on these early ventures - and adventures - are a key part of why entrepreneurs can't imagine doing anything else. 